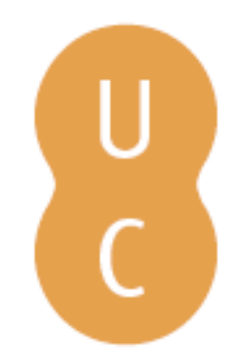

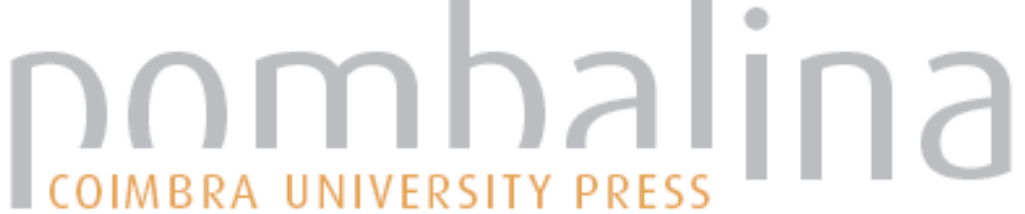

Alcibíades: mobilidade, complexidades

Autor(es): $\quad$ Fialho, Maria do Céu

Publicado por: Imprensa da Universidade de Coimbra; Annablume

URL

persistente: URI:http://hdl.handle.net/10316.2/40867

DOI: $\quad$ DOl:https://doi.org/10.14195/978-989-26-1288-1_8

Accessed : $\quad$ 26-Apr-2023 15:50:07

A navegação consulta e descarregamento dos títulos inseridos nas Bibliotecas Digitais UC Digitalis, UC Pombalina e UC Impactum, pressupõem a aceitação plena e sem reservas dos Termos e Condições de Uso destas Bibliotecas Digitais, disponíveis em https://digitalis.uc.pt/pt-pt/termos.

Conforme exposto nos referidos Termos e Condições de Uso, o descarregamento de títulos de acesso restrito requer uma licença válida de autorização devendo o utilizador aceder ao(s) documento(s) a partir de um endereço de IP da instituição detentora da supramencionada licença.

Ao utilizador é apenas permitido o descarregamento para uso pessoal, pelo que o emprego do(s) título(s) descarregado(s) para outro fim, designadamente comercial, carece de autorização do respetivo autor ou editor da obra.

Na medida em que todas as obras da UC Digitalis se encontram protegidas pelo Código do Direito de Autor e Direitos Conexos e demais legislação aplicável, toda a cópia, parcial ou total, deste documento, nos casos em que é legalmente admitida, deverá conter ou fazer-se acompanhar por este aviso.

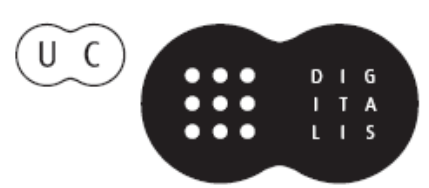




\section{Cosmópolis}

\section{mobilidades culturais às origens do pensamento antigo}

Gabriele Cornelli, Maria do Céu Fialho e Delfim Leão

\section{(coords.)}

IMPRENSA DA UNIVERSIDADE DE COIMBRA 


\title{
Alcibíades: mobilidade, complexidades
}

\author{
(Alcibiades: mobility, complexities)
}

\author{
Maria do Céu Fialho (mcfialhofluc@gmail.com) \\ Universidade de Coimbra, Centro de Estudos Clássicos e Humanísticos
}

Resumo: O jovem Alcibíades possuía todos os atributos que faziam esperar dele um brilhante homem de estado que levaria Atenas à estabilidade política e a uma posição forte na guerra. Sócrates é o único a perceber em Alcibíades a semente das qualidades que o conduziriam à Filosofia e ao Bem. Tentou em vão exercer a sua influência sobre Alcibíades de modo a converter a atracção físico-erótica deste em relação a Sócrates numa relação 'erótica' direcionada para a Filosofia. No entanto, o eros de Alcibíades manteve-se sempre preso ao plano do físico e material, voltado para prazeres físicos, vaidade, ambição e atracção pelo protagonismo fácil. Os numerosos escândalos a que esteve ligado provocaram no povo atracção e receio, e assim Alcibíades foge para Esparta. Como um político inconstante, e após novos escândalos em Esparta, Alcibíades vai para a Pérsia. Tempo depois será recebido em Atenas, de novo expulso de Atenas, até morrer em terra estranha, perseguido por gregos. O itinerário existencial de Alcibíades converte-o num ícon da crise ateniense ou, mais latamente, num ícon da crise das sociedades democráticas de todos os tempos.

Palavras-chave: Alcibíades; Atenas; Sócrates; eros; crise democrática

Aвstract: The young Alcibiades has all the attributes that made people expect from him to become a brilliant politician and to lead Athens to political stability and to a strong position in the ongoing war. Socrates is the one who perceives in Alcibiades the seed of qualities that can lead him to Philosophy and to the Good. He tried in vain to exercise his influence on him by converting Alcibiades' physical-erotic attraction regarding Socrates into an 'erotic' attraction regarding Philosophy. However, Alcibiades' eros always remained at a physical-material level, directed by physical pleasures, vanity, ambition and attraction for protagonizing easily. The numerous scandals to which he was connected provoked people's attraction and fear, so that Alcibiades fled to Sparta. As an inconstant politician, and after new scandals in Sparta, Alcibiades went on to Persia and thereafter was received again in Athens and again expulsed from Athens, until he died abroad, persecuted by Greeks. Alcibiades' existential itinerary converts him into an icon of the Athenian crisis or, more broadly, into an icon of the crisis of democratic societies at any time.

KEYwords: Alcibiades; Athens; Socrates; eros; democratic crisis

$\mathrm{Na}$ história de um povo, seja em tempos de paz e prosperidade, seja em tempos de crise, há, por vezes, figuras políticas cuja memória fica como emblemática da sua época, ou de um segmento particularmente definido da época em que dominaram o espaço público. 
Essa consciência do espelhamento de uma época ou de uma cultura numa figura preponderante, ou, por exemplo, na figura de um fundador, tiveram-na já os Antigos, reconhecendo, através da biografia literária ou na retratística, dada em vários géneros literários, que uma vida pode condensar, por sua vez, as características da natureza de uma cultura ou o percurso histórico de uma comunidade, ou ainda dar voz à complexidade de um processo histórico em que é agente. Neste último caso, ocorre-nos, de imediato, o exemplo dos discursos estratégicos postos na boca de protagonistas em Tucídides, no caso anterior ocorrem-nos os múltiplos exemplos das Vitae de Plutarco, começando pelas dos fundadores Teseu e Rómulo, cujo itinerário biográfico antecipa o destino das cidades que fundam.

A extraordinária perspicácia e hermenêutica das fontes fez com que Plutarco traçasse, desse modo, a Vida de Alcibiades. O que prova a verdade do que se deixa inferir da famosa afirmação de Aristóteles no cap. IX da sua Poética: se a poesia é mais filosófica do que a história a esta, ainda que num grau menor, é reconhecida uma dimensão filosófica, naquilo que pode conter de universalidade no individual, no acontecido, quando convertido em narrativa.

Assim, a complexa e fascinante figura de Alcibíades deu motivo a narrativa histórica e filosófico-ficcional, de modo que entre ambos os tipos de fontes se gerou uma interacção a ponto de fixar o retrato e biografia deste homem, ateniense nascido de gente ilustre, em meados do séc. $\mathrm{V}$ a. C., dotado de invulgar inteligência e beleza, mas marcado, em igual proporção, por uma vaidade e arrojo sem limites. Alcibíades era descendente de heróis da saga épica: Clínias, seu pai, pertencia à família dos Eupátridas, que se dizia descendente de Ájax, e alia-se, pelo casamento, a uma das famílias mais notáveis de Atenas, a dos Alcmeónidas, a que pertencera Clístenes. Sua mãe era filha de Mégacles, irmão de Péricles. Seu pai combateu os Persas em Artemísio e os Beócios em Coroneia, onde morreu. Alcibíades não foi, assim, educado pelos seus progenitores, mas entregue à tutela de Péricles e de Arífron' ${ }^{1}$.

A coragem do pai parece ser espelho dos futuros feitos militares do filho. Péricles e Arífron foram então seus tutores. Plutarco faz questão de informar o leitor de que Alcibíades teve uma mulher da Lacónia, como ama, de que nos dá o nome, Amicla, como que para deixar no ar essa ligação a Esparta² ${ }^{2}$ premonitória da que futuramente terá, a par da ascendência ateniense - e como pedagogo um homem chamado Zópiro, de quem mais nada se diz.

Votado a um percurso que o leva do político demasiado jovem e promissor, ao jovem debochado, amante de prazeres descomedidos, arrojado nas empresas

\footnotetext{
${ }^{1}$ Sobre a expressividade das etimologias dos antepassados de Alcibíades, veja-se Pérez Jiménez 2006: 129 n. 2. Pinheiro 2013: 169 nota o quanto esta ausência dos pais como educadores é significativa.

${ }^{2}$ Tenhamos, no entanto, em conta a informação de Plutarco, Lyc. v14. 2-4, de que as amas lacónias eram muito apreciadas e, por isso muito requisitadas. Cf. Pinheiro 2013: 169 n. 260.
} 
militares que calcula para seu proveito, ele revela-se capaz de ir trocando a pólis de que é cidadão (ou aquela que o acolhe, como é o caso de Esparta) pelo inimigo desta, vezes sucessivas, num tortuoso itinerário, a que se adapta como um camaleão ${ }^{3}$.

Ora fugido ora expulso de Atenas, acolhido e fugido de Esparta, conviva de cortes dos Persas, que vai traindo, bem como aos Gregos, ele consegue sempre provocar os sentimentos contraditórios de saudade, medo, afecto e ódio nos seus concidadãos. Tal fenómeno é claro nos livros V sqq. de Tucídides. Aristófanes, ao jeito dramático, fala da relação Atenas-Alcibíades personificando a cidade (como, de resto, o fazem elegíacos e trágicos, que "ama-o, detesta-o e todavia

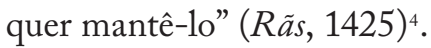

Ora esta origem nobre, beleza, cultura, inteligência, mas também a manifestação de uma insaciável sede de hegemonia e de protagonismo, por parte do jovem, bem como a sua labilidade, demonstrada na facilidade em trair aliados e encontrar outros novos, para os trair em seguida, durante o desenvolver das hostilidades entre o lado ateniense e o espartano, adequam-se a uma leitura da natureza e vida de Alcibíades, simultaneamente como fruto e como espelho da própria Atenas em tempo de crise profunda: a existência de Alcibíades (450-404 a. C.) acompanha o turbilhão de acontecimentos e de instabilidades da Guerra do Peloponeso, desde o seu início (431 a. C.) até ao seu desfecho e à derrota final de Atenas na batalha de Egospótamos (405 a. C.) - ou melhor, até um tempo em que, moralmente, toda a Hélade se derrotou a si mesma.

Com efeito, a beleza, inteligência, capacidade de sedução e gosto por se converter em centro das atenções leva a que Alcibíades fosse já figura pública, amada ou detestada, na sua adolescência ${ }^{5}$. O jovem administrou com astúcia esta sua imagem em espaço público, antes de poder intervir na vida política, por não ter atingido idade para isso. Entrou em várias competições desportivas pan-helénicas, subsidiou um número considerável de coreguias, combateu com denodo em várias batalhas da guerra civil que assolava a Hélade (Délio, Potideia). Esteve na primeira linha da expedição naval de triste memória a Melos (416 a. C.) ${ }^{6}$, após se ter quebrado a Paz de Nícias. Com efeito, ele pertencia àquele tipo de jovem ateniense cuja carreira dependia da guerra. Passa, assim, a integrar-se no sector de vozes partidárias da reabertura de hostilidades. Por meio do engano - e assim no-lo faz entrar Tucídides na turbulenta movimentação política em Atenas (5. 43 sqq.)

${ }^{3}$ Assim o apresenta Plutarco (Vida de Alcibiades, 23.3). Vide Fialho 2008: 114-115.

${ }^{4}$ Este verso é citado por Plutarco (Vida de Alcibiades, 16.3)

${ }^{5}$ Plutarco consegue insinuar, já desde o início da biografia de Alcibíades, a presença destas características, contraditórias, desordenadas, através da própria estrutura peculiar de um 'prólogo integrado': vide Stadter 1988: 275-295. Sobre a semiótica da organização propositadamente caótica dos primeiros capítulos vide Duff 2003: 94 sqq.

${ }_{6}^{6}$ Tucídides 5.84 sqq. 
- torna-se promotor de uma aliança defensiva com Argos, que incluia Mantineia e a Élide. Argos, por seu turno, emprenderá en 419 um ataque a Epidauro, ao qual os Espartanos reagiram, atacando a Argólida, defendida por Mantineia e pela Élide. Alcibíades incrementa as hostilidades em relação à Arcádia e defronta-se com aqueles em Mantineia, en 418. Vencem os Espartanos, o que teve como consequência a queda de Argos que acaba por assinar a paz com Esparta, até que novo volte-face leve Argos a renovar a quebrada paz com Atenas. Corinto, por sua vez, aproxima-se de novo de Esparta, o que provoca a apreensão dos Atenienses. Nícias aparece como partidário de nova tentativa para consolidar a paz e recuperar Anfípolis, ao passo que Alcibíades aparece como defensor de uma forma de imperialismo agressivo, como forma de defesa pelo ataque. Tinha do seu lado as gerações mais novas, ansiosas por granjear glória e fortuna na guerra.

Tucídides apresenta-no-lo a discursar, pela primeira vez, na Assembleia, aquando da ponderação sobre a eventual pertinência da expedição à Sicília (6. 15 sqq.) e sobre as boas razões para a comandar. Ora há que atender ao facto de as repercussões e consequências da capacidade persuasiva de caudilhos na Assembleia se terem amplificado de um modo incomensurável, já que, com a apreensão reinante na Ática rural, os camponeses tinham deixado os seus campos para se refugiar no coração da pólis. Assim, mesmo aqueles que, tendo direito de cidadania, raramente se deslocavam até à cidade para participar na vida política, estavam agora ali presentes e afluíam à Assembleia, ainda pouco familiarizados com os golpes de retórica e, por isso, facilmente manipuláveis ${ }^{7}$.

Coincidente com a deliberação da expedição à Sicília, estala o escândalo da delapidação dos hermes e, logo de seguida, o da paródia dos Mistérios. Fosse ou não da responsabilidade de Alcibíades e de seus amigos, o que é certo é que a questão foi levada a instâncias judiciais, com o retardamento necessário para que Alcibíades chegasse à Sicília e, para que aí, a nau 'Salamina' o fosse buscar para o trazer de volta a Atenas, para ser julgado. Ora Alcibíades, uma vez aportado a Túrios, escapa para o lado espartano para, mais tarde, na sequência de uma situação melindrosa, de quebra de lealdade em relação ao rei de Esparta, Ágis, procurar refúgio na corte do sátrapa Tissafernes.

Por ironia do destino, é aquele que os Atenienses temiam como potencial tirano que irão chamar mais tarde, após se instalar em Atenas o governo oligárquico dos Quatrocentos (411 a. C.). Alcibíades acorre, após ter já demonstrado, em campanha, que está com os Atenienses, com toda a pompa e circunstância, que eram manifestação da sua alegria e saudades da pátria (cf. Alc 32. 1) e que Plutarco não deixará de descrever (Alc. 32.2), a defender, com a sua armada, os ideais democráticos de Atenas - já a oligarquia havia caído, graças também à sua acção à distância.

\footnotetext{
${ }^{7}$ Blásquez, López Melero \& Sayas 1999: 554-555.
} 
Com o júbilo da multidão contrasta, de novo, a inveja e a apreensão pelo que Alcibíades, de novo em Atenas, poderia representar: Trasibulo constitui uma das vozes congregadoras deste mal-estar. A guerra aproxima-se do seu fim e estão definitivamente lançadas as sortes. A vida de Alcibíades também. Alcibíades tentou, em vão, chamar a atenção dos generais para a má estratégia por que optaram para a batalha de Egospótamos que se prepara (405 a. C.) e em que os Atenienses perderão estrondosamente a batalha e a guerra. Não foi ouvido, mas desprezado. $\mathrm{O}$ seu apurado sentido das circunstâncias fá-lo perceber o perigo que corre, por parte de Gregos, Atenienses e Espartanos. Novamente se acolhe em espaço persa, na corte de Farnábazo. Aí chegará o braço da intriga grega e a perseguição sem tréguas levará à sua morte em 404 a. C., um ano após a falência ateniense.

Por seu turno, a relação entre Alcibíades e Sócrates, que as fontes documentam até um certo momento na vida do jovem político, e que Platão assume nos seus diálogos, redobra o interesse por esta complexa figura: ter-se-ia o próprio Sócrates rendido ao fascínio de Alcibíades? E o que provocou em Alcibíades o fascínio por Sócrates - um fascínio intermitente, já que ora Alcibíades se aproxima de Sócrates e profere discursos apologéticos sobre o filósofo, ora Sócrates o procura, como que dando-lhe caça. A mesma labilidade parece aproximar e afastar o jovem pupilo de Péricles do filósofo. A relação seria ambígua, ou aparentemente ambígua, sob o signo de eros.

Levanta-se aqui a questão: no contexto dos diálogos é praticamente impossível apurar o grau de referências reais numa escrita em que Platão comunica e filosofa através de situações maioritariamente ficcionais, em que se esbate, frequentemente, a fronteira entre o pensamento do mestre e do seu discípulo, fundador da Academia. Seja como for, é pelo punho de Platão que chegamos ao que ele nos quer fazer perceber do cariz relacional entre Sócrates e Alcibíades. Assim sendo, é Platão quem assume, também, essa ambiguidade - ou aparente ambiguidade - e envolve a natureza de um elo erótico numa espécie de enigma, em que não deixa de estar imbricada a natureza volúvel de um Alcibíades belo, inteligente, atraído por Sócrates e, simultaneamente, por toda a espécie de prazeres não-socráticos.

No pórtico do Protágoras (309a-c) Platão joga com a tradicional imagem da caça, aplicada à perseguição amorosa desde a lírica arcaica, para referir, na boca de uma personagem, a do Companheiro, a relação entre Sócrates e Alcibíades. Penso que pela voz do Companheiro dá Platão eco da voz corrente do vulgo, ao mesmo tempo que, num outro registo, insinua a perseguição própria da filosofia. Platão cria como que um breve 'suspense' para o desfazer, no decorrer do diálogo, com a explicação socrática:

Companheiro - De onde vens tu, ó Sócrates? Está-se mesmo a ver: da caça ao jovem Alcibíades, não é assim? A propósito, quando o avistei, esta manhã, pareceu-me já um belo homem; e - isto aqui entre nós, Sócrates - um homem 
feito, até com barba a despontar.

Sócrates - Ora, e então? Não és tu admirador de Homero, que diz que a idade mais grata é a da primeira barba, a que tem agora Alcibíades?

Companheiro - É certo. E o que há de novo? Vens de junto dele, não vens? Que tal te tratou o nosso jovem?

Sócrates - Bem, sobretudo hoje - pelo menos, pelo que me pareceu -, pois pôs-se do meu lado e fez várias intervenções em meu favor. Sim, venho agora mesmo de junto dele. Por sinal que te quero contar algo digno de nota: apesar de ele estar presente, não lhe prestei grande atenção e, muitas vezes, até me esqueci dele.

Companheiro - Mas que coisa tão extraordinária vos terá acontecido, a ti e a ele? Não me digas que encontraste algum outro jovem ainda mais belo do que ele aqui na nossa cidade?

Sócrates - E muito mais!

Companheiro - Que dizes? Aqui da cidade ou estrangeiro?

Sócrates - Estrangeiro.

Companheiro - De onde?

Sócrates - De Abdera.

Companheiro - E pareceu-te assim tão belo esse estrangeiro a ponto de o achares ainda mais belo que o filho de Clínias?

Sócrates - E como é que aquele que é mais sábio, meu caro, não há-de parecer o mais belo?

Se o próprio Sócrates não descarta a atracção por jovens belos - especificamente Alcibíades - logo manifesta a sua capacidade de a superar em função de uma beleza superior, a da sabedoria. Uma não exclui, mas, porventura, abre para a outra.

É de recordar um passo eloquente do Górgias (481d-482a). Na sequência da discussão sobre os efeitos perniciosos da retórica, que defende a injustiça, Sócrates dirige-se a Cálicles, exemplificando até que ponto a comunicação é possível entre os homens, já que há impressões e sentimentos (pathos) comuns entre os homens. A saber:

Sócrates - Eu constatei, e é isso que me faz falar assim, que nós experimentamos ambos o mesmo tipo de sentimento, já que ambos amamos (erasthai) - tendo cada qual dois objectos do seu amor: eu, Alcibíades, filho de Clínias, e a filosofia, e tu o Demos ateniense e Demos, filho de Pirilampo.

...Quanto ao filho de Clínias, ora diz uma coisa, ora diz outra; a filosofia, em contrapartida, diz sempre o mesmo. E diz precisamente aquilo que agora te provoca espanto.

Este erasthai por dois objectos distintos, sendo um deles instável e inconsequente (o que a História prova) e o outro consistente, permanente e, ao mesmo 
tempo revelador de verdades insuspeitas à partida, só pode, quanto a Sócrates, abrir um caminho - o da tentativa de converter o primeiro objecto ao segundo e torná-lo consistente, permanente, amante da verdade, em suma, da filosofia.

Com a escolha deste exemplo deve Platão ter querido reforçar a defesa da imagem do mestre como aquele que procura conduzir os jovens à verdade e não acompanhá-los na corrupção de costumes. De qualquer modo, o exemplo fala por si.

Xenofonte, em Memoráveis, 1, 2, 12 atribui a Alcibíades precisamente três defeitos particularmente graves, segundo a ética grega: o ser akratestatos (com falta de autodomínio), bybristotatos (dado aos excessos), biaiotatos ${ }^{8}$.

Que teria ligado Alcibíades e Sócrates? É demasiado simplista, como já se viu, a resposta: "uma atracção mútua". À atracção socrática parece Platão querer dizer que a reforçava a vontade de converter o autodomínio em constância, o excesso em equilíbrio, a violência em espanto filosófico. Nunca Sócrates logrou levar a cabo tal empreitada. A Tyche, como um vento, sempre interpunha entre ambos as más influências de outros jovens corruptos ${ }^{9}$. Por que motivo alimentou então Sócrates esse intuito, até Alcibíades seguir os seus tortuosos caminhos, fora de Atenas?...Deixo a questão em suspenso.

Impõe-se agora considerar o Banquete. Muito se escreveu já, por parte de eminentes autoridades, para que se espere que aqui seja dito algo de novo sobre este diálogo. Mais uma vez tomamos consciência de que não é história, mas discurso filosófico sob a forma de genial ficção que temos diante de nós. Como tal, os elementos da dimensão conotativa do discurso são filosoficamente importantes porque Platão assim o quis. Numa peculiar forma de narrativa, que não se encontrou nos diálogos anteriores, mas que está presente neste: uma cadeia de mediações de relato em terceira instância - alguém que ouviu o relato de alguém que ouviu, distante no tempo, as palavras dos interlocutores no Banquete. No caso do discurso de Sócrates, reproduzindo o da sacerdotisa Diotima, teremos uma quinta instância. Este processo foi analisado por Cornelli ${ }^{10}$.

A relação do autor Platão com a narrativa é expressiva: dilui-se a nitidez e a garantia de que os acontecimentos no Banquete foram exactamente assim, sem traições das várias memórias ficcionais envolvidas. Ou seja: para além da abordagem caleidoscópica de Eros, feita por cada conviva, de acordo com o seu género de discurso e de praxis, esta cadeia de discursos simposiásticos é coroada pelo discurso de Sócrates que reproduz um outro discurso, uma explicação antes ouvida a quem a tinha recebido e que integra os discursos anteriores, produzidos por uma visão de eros que partilha pontos comuns, ainda que particulares, com

\footnotetext{
${ }^{8}$ Romilly 1995: 46.

${ }^{9}$ Ramsey 2012 : 63. Vide autem Pérez Jiménez 1973 : 103 sqq.

${ }^{10}$ Cornelli 2013: 141 sqq.
} 
o mito de Eros filho de Poros e Penia. Esta intervenção integradora de Sócrates ${ }^{11}$ insinua a sua conversão em Eros presentificado: um eros unificador e condutor à filosofia - o verdadeiro eros filosófico. Blyth defende, com pertinência, que nos diálogos em que Sócrates fala de eros não se apresenta como erastes, mas como alguém competente para falar das manifestações de eros nos outros homens ${ }^{12}$. O seu eros é um derivado, orientado para o grau mais elevado: o da filosofia.

A intempestiva chegada de Alcibíades, vindo de bródios nocturnos, ébrio e insistindo em se associar ao convívio faz esperar a dispersão ou perturbação do banquete. E, todavia, no seu jeito de surpreender com o decurso insuspeitado dos acontecimentos, Platão concebe este Alcibíades ébrio capaz de construir um discurso com a sinceridade e o despudor dos ébrios. O discurso não é sobre eros, mas converte-se numa apologia de Sócrates, que se converte, definitivamente, em representante ou presentificação do próprio Eros, na forma mais elevada.

Fica claro, nessa sinceridade do discurso, que Sócrates não tinha como fim a união carnal com Alcibíades, mas visava uma relação espiritual, alimentada ou orientada para a filosofia. A tentativa frustrada de Alcibíades de seduzir Sócrates havia sido em vão, no banquete em sua casa. Sócrates reagira com o seu autodomínio (karteria) proverbial - o mesmo que o fazia suportar o frio intenso, prescindindo de agasalho ${ }^{13}$. E, no entanto, para além dessa atracção por parte de Alcibíades, que visava a união carnal, Alcibíades confessa, numa bela imagem, que a fealdade socrática é apenas aparente e Sócrates contém, em si, não visível, uma inigualável beleza interior. Esse parece constituir o motivo de atracção de Alcibíades por Sócrates. Que nos quer dizer Platão? Que Alcibíades fora capaz de vislumbrar a verdadeira beleza de Sócrates, a do espírito, que o poderia ajudar a erguer aos caminhos da sabedoria verdadeira e da filosofia. No entanto, Alcibíades, por força dos seus hábitos e das suas habituais companhias, havia confundido os estádios de eros e não fora capaz de se elevar do plano sensorial mais imediato e primário ${ }^{14}$.

Ao dar assim por findo o seu discurso, Sócrates começou a receber as felicitações de todos; apenas Aristófanes se preparava para dar uma réplica qualquer, alegando que tinha sido ele o visado com a alusão à tal teoria...Mas eis que de repente batem à porta do pátio com enorme alarido, provocado, segundo tudo leva a crer, por um bando de foliões, e ouve-se o canto de uma flautista. Exclama Ágaton para os criados:

Então não vão ver o que é? Se for algum dos nossos conhecidos, mandem entrar. Se não, digam que já acabámos de comer e estamos a descansar.

Não muito depois ouvem, de facto, a voz de Alcibíades no pátio, já bastante

\footnotetext{
${ }_{11}$ Azevedo 1991: 20-21.

12 Blyth 2012: 34-35.

${ }^{13}$ Romilly 1995: 47.

${ }^{14}$ A tradução citada é a de Azevedo 1991.
} 
tocado, a perguntar aos berros por Ágaton e a exigir que o levassem junto dele. Levam-no então até junto dos outros convidados, amparado pela flautista e por alguns dos da comitiva. À entrada da sala detém-se, com a fronte cingida por uma espessa coroa de folhas de hera e de violetas, a cabeça coberta por uma infinidade de fitas. (Platão, Banquete, 212 c-e)

O discurso de Alcibíades constitui o mais belo discurso sobre Eros $^{15}$, como se Sócrates incarnasse o daimon, de modo misterioso e desconcertante ${ }^{16}$, já que a atracção de Sócrates por Alcibíades não correspondia aos termos da atracção física de Alcibíades por Sócrates. Este dominava-se de modo sobre-humano, consoante um episódio exemplar narrado por Alcibíades, como se quisesse dar o exemplo e o sinal de que a atracção erótica se deve elevar a um plano mais alto - o que Alcibíades não acompanha:

...Da vez seguinte, porém, preparei-lhe nova cilada: mal o jantar acabou, prolonguei a conversa pela noite adiante, de modo que, quando quis despedir-se, aleguei que era já muito tarde e obriguei-o a ficar. Descansou, portanto, no leito contíguo ao meu - o mesmo em que tinha jantado - e naquele aposento ninguém mais dormiu, além de nós...foi aí, no coração, na alma ou como deva chamar-se, que me sacudiram e me morderam as palavras da filosofia...sim, digo-o na presença ...de todos vocês, que partilham do delírio e da divina loucura da filosofia... Ora bem, meus senhores, logo que a luz se apagou - já os criados tinham saído - achei que devia deixar-me de subterfúgios e dizer-lhe, com toda a franqueza, aquilo que pensava:

“...Acho que és o único homem digno de ser meu amante mas, ou me engano, ou tens receio de te declarares a mim. Ora as minhas disposições aí as tens: a meu ver, seria uma rematada tolice não te corresponder nesse ponto...pois não há nada que tome tão a peito como a ideia de me aperfeiçoar até onde me for possível, e não creio que para isso possa contar com um auxiliar mais preciso do que tu! Precisamente por seres o homem que és, teria muitos mais motivos para me envergonhar, junto de homens inteligentes, por não te corresponder com a minha afeição, do que, em caso contrário, perante o vulgo e os imbecis”. Depois de me escutar, eis que me responde com essa ironia refinada, que é seu jeito característico:

${ }^{15}$ Vide Cornelli 2013: 145: “A própria estrutura do diálogo não deixa dúvidas com relação à centralidade da relação entre os dois: o discurso de Diotima pareceria de fato o ápice da discussão sobre o amor, do ponto de vista teorético, e o diálogo poderia terminar aqui. Todavia, é exatamente nessa altura que Alcebíades, máscara de Eros e de Dioniso, modelo do amante, entra em jogo. De certa forma, é o caso de dizer, todos os discursos, para brincar com o léxico do próprio "Banquete", ansiavam e sentiam falta da entrada da própria máscara do amante, encarnação de Eros: Alcebíades. Em sua grande habilidade literária, Platão parece conseguir fazer convergir todos os discursos para o mise-en-scène final da entrada de Alcebíades."

${ }^{16}$ Sobre a tradição, na filosofia e literatura antigas, do Sócrates daimonios, vide Hershbell 1988: 365-382. 
"Meu querido Alcibíades, talvez tu não sejas, a bem dizer, parvo nenhum, se é verdade o que dizes a meu respeito e se existe de facto em mim um poder especial, que teria o condão de te tornar melhor! Foi certamente alguma beleza insuspeitada que tu viste em mim, bem diferente dos teus encantos físicos...E se, ao descobri-la, te propões partilhá-la comigo e trocar beleza por beleza é porque calculas obter à minha custa uma vantagem, e não pequena: nada mais nada menos do que adquirir uma beleza real pelo preço de uma beleza aparente...Contudo, meu excelente amigo, ...a verdade é que os olhos da razão só começam a discernir com clareza quando os do corpo se preparam para abandonar o seu vigor...Mas tu ainda estás longe disso!"

“...Pois certifico-vos, pelos deuses e pelas deusas, que, depois de passar a noite com Sócrates, nada mais tinha acontecido, ao levantar-me, do que se tivesse dormido com meu pai ou com um irmão mais velho! Depois disto, imaginam o meu estado de espírito?" (Platão, Banquete, 217d-219d)

A segunda e derradeira interrupção do banquete pelos acompanhantes ébrios de Alcibíades, e pelas flautistas que os acompanhavam apenas sublinha a distância entre o filósofo e o seu amante - que, todavia, acabara de proferir o mais belo de todos os discursos. As contradições do diálogo são também, de algum modo, as próprias contradições de Alcibíades.

É bem provável que Platão, ao apresentar assim Alcibíades, acompanhado pelo grupo de estúrdia nocturna habitual, não queira descartar a hipótese de, pelo menos, Alcibíades se prestar a ser objecto de suspeitas quanto ao sacrilégio dos Hermes decepados ${ }^{17}$.

Em suma, o fundador da Academia apresenta-nos os caminhos desencontrados entre Sócrates e Alcibíades, ainda que ligados por uma atracção mútua.

À pergunta deixada em suspenso "que teria ligado Alcibíades e Sócrates?", já se respondeu parcialmente. Quanto à caça 'movida' por Sócrates a Alcibíades é dúbia, como se disse, já que o termo é empregue na linguagem erótica e na busca filosófica. Também Plutarco emprega o termo:

O amor de Sócrates por Alcibíades, embora contasse com muitos e poderosos rivais, dominava, por vezes, Alcibíades. É que os discursos do filósofo tocavam os dons inatos do carácter do jovem e mexiam com o seu coração até às lágrimas. Mas outras vezes, porém, entregava-se aos seus aduladores, que lhe acenavam com prazeres inúmeros, e escapava, então, a Sócrates. Este movia-lhe caça, como se de um escravo fugitivo se tratasse - era o único homem que lhe inspirava respeito e temor; pelos demais sentia desprezo. (Plutarco, Vida de Alcibiades, 6.1)

\footnotetext{
${ }^{17}$ Cornelli 2013: 146-147.
} 
Penso que, a alguns séculos de distância, lendo e ponderando as fontes de que dispunha, os relatos que até ele chegaram, Plutarco percebeu que processo ligou Sócrates a Alcibíades.

Desde muito jovem, pela sua beleza, riqueza e liberdade de costumes Alcibíades vivia rodeado de aduladores e de jovens que o acompanhavam nos seus excessos nocturnos. Diz Plutarco que só Sócrates se apercebeu da semente de arete que por natureza habitava o seu espírito e propôs-se fazê-la germinar pela paideia e pela filosofia. O jovem dava mostras de corresponder até que, entre o mestre e o discípulo se interpunham, como por má fortuna (tyche), as más companhias. O jovem escapava-lhe das mãos. Sócrates perseguia-o e Alcibíades voltava, como que arrependido, para logo se deixar levar pela sua irresistível philotimia e philoneikia.

Pensando, numa derradeira tentativa, convertê-lo através desse rasgo de philotimia, Sócrates faz com que seja Alcibíades a receber o prémio que lhe tinha competido a ele, Sócrates, na batalha de Potideia, em que lutaram juntos ${ }^{18}$ :

O prémio de mérito cabia, com toda a justiça, a Sócrates. No entanto, como os generais mostravam o desejo de distinguir Alcibíades com esta honra, em virtude da sua alta posição, Sócrates, que pretendia estimular no jovem a ambição (to philotimon) de praticar acções belas, foi o primeiro a testemunhar em seu favor... (Plutarco, Vida de Alcibiades, 7.5)

Em vão o fez. Cada vez mais, Alcibíades se deixava dominar pelas suas paixões e pela adulação e vício. Na batalha de Délio, em 424, na retirada, Alcibíades enxergou Sócrates, a pé, e precipitou-se a cobrir a sua retirada.

Como disse em outro lugar, esta cena assume quase carácter simbólico em Plutarco ${ }^{19}$. Desde então, parece que Sócrates desistiu de conduzir Alcibíades pelos caminhos da filosofia ${ }^{20}$.

Aquando da expedição à Sicília, diz Plutarco que 'Sócrates, o Filósofo, não era a favor da expedição’. Esta forma de se expressar deixa perceber o estranhamento que se foi criando entre as duas figuras. E a expedição à Sicília marca as fugas, exílios, traições, jogos duplos de Alcibíades.

Tucídides, na sua História da Guerra do Peloponeso, 6.15-17, esboça o retrato de Alcibíades através de um conjunto de reflexões, a servir de preâmbulo ao

${ }^{18}$ Sobre as acepções positivas ou negativas do termo, consoante os contextos vide Fialho 2008: 114, n. 11 e Frazier 1988: 109-127.

${ }^{19}$ Fialho 2010: 23.

${ }^{20}$ Nota Cornelli 2013: 151-152, citando Giorgini, que: "Esta philotimía, do qual Alcebíades é exemplo quase que paradigmá- tico no mundo antigo114, leva-o por um lado a se afastar de Sócrates, fugindo assim de seus conselhos e, por outro, a sentir vergonha de sua própria fraqueza. Diz bem Giorgini que, "sem sombra de dúvida, a figura de Alcebíades representou a mais ampla derrota, tanto da educação ateniense como da pedagogia socrática" (Giorgini 2005: 454)." 
discurso de Alcibíades perante a Assembleia (típico dos discursos postos por Tucídides na boca das suas personagens), com o intuito de convencer os Atenienses decidirem-se pela expedição à Sicília:

Incitava à expedição com mais zelo Alcibíades, filho de Clínias, que queria opor-se a Nícias, não só porque estava em desacordo noutras posições políticas, mas também porque tinha sido mencionado por aquele de maneira difamatória e, sobretudo, porque desejava ardentemente ser comandante e tinha a esperança de que a Sicília e Cartago fossem conquistadas por meio da sua intervenção $\mathrm{e}$, se fosse bem-sucedido, isso seria útil aos seus interesses particulares, quer no que diz respeito à riqueza, quer à glória pessoais. $\mathrm{Na}$ realidade, sendo tido em alta estima pelos seus concidadãos, tentava servir os seus caprichos, que eram bem maiores que o património de que dispunha... ... ...e embora Alcibíades tivesse administrado os negócios públicos da cidade muito bem, [os Atenienses] sentiam-se assustados com o seu comportamento privado... .......Alcibíades adiantou-se então e deu aos Atenienses os seguintes conselhos:

-Atenienses, pertence-me a mim, mais do que a outros o comando desta expedição...e também penso que sou merecedor dele. A verdade é que sou especialmente criticado por coisas que não só trazem glória aos meus antepassados e a mim próprio, mas também beneficiam a nossa pátria.... ... ...Além disso, eu distingo-me na cidade financiando coros e outras actividades, coisas que naturalmente provocam inveja nos meus concidadãos, mas para os estrangeiros indicam verdadeiro poder... .......Na verdade eu sei que tais homens e todos os outros que se notabilizam em algo de grandioso, enquanto vivem, são vistos como causadores de problemas, em especial pelos seus pares... ... ...portanto, uma vez quesão estas as minhas ambições e por causa delas sou censurado no que respeita à minha vida privada, considerai os meus actos ao serviço da cidade e vede se eu os administro pior do que qualquer outro... ... ...Portanto, a minha juventude e aquilo que parece ser a minha extraordinária falta de bom-senso fizeram frente aos Peloponésios... (Tucídides, 6.5-17)

Ainda em Atenas, Plutarco narra o episódio da chegada em atraso de Alcibíades e do seu grupo de excessos ao banquete do seu amante Ânito - precisamente o mesmo que esteve envolvido no processo do julgamento de Sócrates. Ao irromperem na sala onde se encontravam os convivas, Alcibíades dá ordens aos escravos para que lhe arrecadem das mesas do anfitrião metade das taças de ouro. Este banquete replica a chegada em atraso e embriaguez do Alcibíades platónico, mas dá-nos a imagem de Alcibíades fora da influência de Sócrates ${ }^{21}$.

Ora acontecia que este homem, Ânito, estava tomado de amores por Alcibíades e, numa ocasião em que recebia uns hóspedes seus, convidou também Alcibíades

${ }^{21}$ Sobre este episódio vide Cerezo Magán 1999 : 171-180. 
para a ceia. Este declinou o convite mas, depois de se entregar ao vinho em sua própria casa, veio com os seus companheiros, em cortejo de ébrios, até à casa de Ânito. Parou à entrada da sala de jantar e, ao ver as mesas repletas de taças de prata e de ouro, deu ordens aos seus escravos para recolherem metade das taças e as levarem para sua casa. Ele, por sua vez, nem se dignou entrar e foi-se embora, depois desta proeza. 6. Os convivas, indignados, protestavam perante a insolência e a arrogância com que Alcibíades havia tratado Ânito, ao que este retorquiu: "dizei antes que agiu com cordura e bondade, pois poderia ter levado tudo consigo e deixou-nos uma parte".

(Plutarco, Vida de Alcibiades, 4.5-6)

Falhou Sócrates na sua paideia? Sim e não. Creio que é perspicaz a leitura plutarquiana: Sócrates viu, naquele belo adolescente, inteligente e devasso, a semente dada pela natureza que, alimentada, desabrocharia e o levaria pelos caminhos da sabedoria à filosofia e à virtude. Aderiu a esse projecto que tomou a peito e procurou, de todas as formas, converter Alcibíades. É certo que Alcibíades deve ter sido sensível à paideia socrática até certo ponto, já que se apercebeu da 'beleza' de Sócrates e se deixou atrair por ela. Todavia, não conseguiu descolar do chão a que o prendia a vaidade e ambição, o amor-próprio e o gosto pelo exibicionismo, a propensão para o escândalo, para as más companhias e para os vícios. Assim, a sua atracção por Sócrates manter-se-ia, como dá a entender Platão, num plano confuso, de carnalidade rasteira e de fascínio pelo seu espírito. A empresa de Sócrates não podia resultar, já que os seus discursos são desencontrados e Alcibíades é engolido pelo turbilhão de vícios pessoais e colectivos da cidade em crise, comparado por Plutarco, nas suas mudanças várias de faç̧ão, a um camaleão:

3. Se ele era famoso e admirado pela sua actuação política, não o era menos pela sua vida privada: seduzia e conquistava o povo ao adoptar os hábitos de vida lacónios. Quantos o avistavam de barba rapada, a tomar banho em água fria, a comer o habitual pão de cevada e o caldo negro, dificilmente acreditavam no que os seus olhos viam e interrogavam-se se aquele homem já tivera algum dia um cozinheiro em sua casa, ou se já teria visto um perfumista ou consentido que o seu corpo envergasse vestes de Mileto. 4. É que ele possuía um dom único, segundo se diz, entre os muitos de que era detentor, e que constituía uma técnica para prender as pessoas: tal consistia em se adaptar aos seus costumes e modos de vida. Era mais rápido no seu mimetismo que o camaleão. 5. Há uma cor, ao que se diz, que o camaleão não é capaz de tomar - a cor branca -, enquanto Alcibíades era capaz de passar com igual facilidade do bem ao mal e do mal ao bem e não havia comportamento a que ele se não conseguisse adaptar ou que não conseguisse assumir. Em Esparta praticava exercícios físicos, era sóbrio e austero; na Iónia era efeminado, voluptuoso e indolente; na Trácia entregava-se à bebida e a montar a cavalo; quando esteve na corte do sátrapa Tissafernes, ultrapassou em pompa e despesismo a magnificência persa. Isto não quer dizer que lhe fosse fácil abandonar um modo 
de vida para adoptar outro, nem que ele estivesse sempre pronto a mudar, pelo seu próprio carácter, mas antes porque, na medida em que tinha consciência de que, se seguisse a sua própria natureza, iria ter dissabores com aqueles que o cercavam, adoptava então, por sistema, as atitudes e formas adequadas àqueles com quem convivia, e aí encontrava o seu modo de se achar seguro. (Plutarco, Vida de Alcibiades, 23,3-5)

A ambição o move a levar à quebra da Paz de Nícias, a ambição o leva a incentivar a ruinosa expedição à Sicília e a suscitar os amores e ódios da cidade que, provavelmente, o quiseram liquidar pela intriga.

A partir desse momento, a labilidade e as complexidades deste jovem político, tão genial quanto ambicioso, converteram-se numa vida de fugas, traições, de fausto e de perseguição, algo similar ao itinerário da sua cidade em crise. Talvez por isso ela o amasse e odiasse: por se sentir espelhada nele.

Quanto a Sócrates, sai do seu caminho mas, por amarga ironia, é condenado à morte por ter supostamente cometido o que sempre evitou - a corrupção da juventude. Como sublinha Gribble ${ }^{22}$, não foi minimamente Sócrates mas a sociedade quem corrompeu Alcibíades e outros jovens de análogo perfil ${ }^{23}$.

Em conclusão: Em toda a sua vida, pelo seu carácter, qualidades indesmentíveis, conduta política ora brilhante, que levou Atenas a grandes vitórias, ora contraditória, inesperada e de traição (também por se sentir perseguido), Alcibíades consubstancia a própria ambição e espírito de imperialismo atenienses, a que Atenas, a pólis que alcançou as mais altas manifestações do espírito, não soube pôr freio, perdendo progressivamente a sua ética política.

O fascínio que esta personagem exerceu na Antiguidade e continua a exercer até nós está comprovado pelo número de autores antigos, quer contemporâneos quer posteriores, que lhe devotaram atenção, na sua obra ${ }^{24}$.

Considerada a partir dos nossos dias, a existência e destino desta figura vê amplificada a sua dimensão simbólica. Consoante as palavras de Jacqueline de Romilly25: "há na vida de Alcibíades uma espécie de valor paradigmático que a torna simbólica e inesquecível. Ela ganha um sentido em todas as épocas. E também para a nossa ela ganha sentido, talvez mais que para qualquer outra. Alcibíades, como imagem da ambição individualista numa democracia em crise, ilumina, com as suas seduções e os seus escândalos, as nossas próprias crises...”.

22 Gribble 1999: 394. Cf. Becchi 1999: 25-43.

${ }^{23}$ Cf. Ramsey 2012: 62, para quem Platão usa Alcibíades simbolicamente, como representante de uma geração.

${ }^{24}$ Mencione-se Aristófanes, Tucídides, Xenofonte, Platão, Andócides, Teofrasto, a filosofia de tradição platónica, estóicos como Zenão e Cleantes, oradores diversos, historiógrafos dos sécs. IV e III a. C., historiadores romanos, autores de literatura biográfica, de que distingo Cornélio Nepos, e, não esquecer, Plutarco.

${ }^{25}$ Romilly (1995) 32-33. 


\section{BibliografiA}

Azevedo, M. T. Schiappa de (1991), Platão. O Banquete, introd. trad. do grego, notas. Lisboa.

Becchi, F. (1999), "Plutarco fra platonismo e aristotelismo: la filosofia comme paideia dell'anima” in A. Pérez Jiménez, J. García López, R. M. Aguilar (eds.), Plutarco, Platón y Aristóteles. Actas del V Congreso Internacional de la I.P.S. Madrid, 25-43.

Blyth, D. (2012), "Socrates and Platonic models of love" in M. Johnson \& H. Tarrant (eds.), Alcibiades and the Socratic lover-educator. London, 30-44.

Cerezo Magán, M. (1999), "Embriaguez y vida disoluta en las Vidas” in J. G. Monts Cala, M. Sanchez Ortiz de Landaluce, R. J. Jesus Gallé Cejudo (eds.), Plutarco, Dioniso y el vino. Actas del VI Simposio Español sobre Plutarco. Madrid, 171-180.

Cornelli, G. (2013), "Seduzindo Sócrates: retórica de gênero e política da memória no Alcebíades platônico" in G. Cornelli, G. Guerreiro Costa (eds.), Estudos Clássicos I, Coleção Filosofia e Tradição. Brasília.

Duff, T. (2003), "Plutarch on the childhoood of Alkibiades (Alk.2-3)" PCPS 49: 89-117.

Fialho, M. C. (2008), "From flower to chameleon. Values and counter-values in Alcibiades'Life" in J. R. Ferreira, L. Van der Stockt, M. C. Fialho (eds.), Philosophy and society. Virtues and values in Plutarch. Leuven-Coimbra, 107-116.

Fialho, M. C. (2010) "Plutarco. Vida de Alcibiades. Introd. trad. do grego, notas" in M. C. Fialho, n. Simões Rodrigues, Plutarco. Vidas Paralelas. Alcibiades e Coriolano, introd. trad. do grego e notas. Coimbra.

Frazier, F. (1988), “À propos de la philotimie dans les Vies. Quelques jalons dans l'histoire d'une notion" RPh 67.1: 109-127.

Gribble, D. (1999), Alcibiades and Athens: a study in literary presentation. Oxford.

Hershbell, J. P. (1988), "Plutarch's portrait of Socrates”, ICS 13: 365-382.

Pérez Jiménez, A. (1973), "Atitudes del hombre frente a la tyche en las Vidas Paralelas de Plutarco", BIEH 7: 101-110.

Pinheiro, J. (2013), Tempo e espaço da paideia nas Vidas de Plutarco. Coimbra.

Ramsey, R. (2012), "Plato's oblique response to issues of Socrates' influence on Alcibiades: an examination of the Protagoras and the Gorgias" in M. Johnson \& H. Tarrant (eds.), Alcibiades and the Socratic lover-educator. London, 61-76

Romilly, J. de (1995), Alcibiade ou les dangers de l'ambition. Paris.

Stadter, Ph. (1988), “The poems of Plutarch's Lives”, ICS 13.2: 275-295. 